\title{
Brown Adipose Tissue in Children and Its Metabolic Function
}

\author{
Daniel Tews Martin Wabitsch \\ Division of Pediatric Endocrinology and Diabetes, Department of Pediatrics and Adolescent Medicine, Ulm \\ University Medical Center, Ulm, Germany
}

Keywords

Brown adipose tissue $\cdot$ Glucose metabolism · Lipid metabolism

\begin{abstract}
Background: To regulate body temperature, mammals possess brown adipose tissue (BAT), which converts significant amounts of chemical energy into heat. Due to its remarkable energy demand, BAT is currently discussed as a target organ to treat obesity and obesity-related disorders. Summary: Although BAT is predominantly present in infants and its relative mass declines with age, new findings suggest that BAT has a relevant role in the regulation of energy homeostasis as well as in the regulation of the energy substrates glucose and lipids in older children, adolescents, and adults. In this overview, we will outline basic mechanisms of BAT thermogenesis and the recently described physiological relevance of BAT in metabolism in children and adolescents. Key Message: The connection of BAT activity with glucose metabolism and insulin sensitivity seems to be evident from recent studies, implicating BAT as an important influencing factor in the context of metabolic syndrome.
\end{abstract}

(c) 2021 S. Karger AG, Basel

karger@karger.com

(C) 2021 S. Karger AG, Basel

www.karger.com/hrp

Karger!

\section{Introduction}

Mammals possess a specialized tissue that enables survival in the cold, providing a key evolutionary advantage. Although brown adipose tissue (BAT) shares structural similarities with white adipose tissue (WAT), its primary function is not to store energy but to produce heat by oxidizing fatty acids and/or glucose from intracellular energy stores and circulation. This allows survival during nocturnal cold as well as in winter, cold stress at birth, and may be advantageous if macronutrients (especially protein) are limited. In contrast to WAT, BAT is characterized by extensive vascularization and innervation. On the cellular level, brown adipocytes are histologically distinguishable from white adipocytes by their high abundance of lipid vesicles as well as high mitochondrial density, which contributes to the brownish appearance of BAT. These BAT mitochondria are rich in cristae and contain the specific functional protein uncoupling protein 1 (UCP1, Fig. 1) in the inner mitochondrial membrane, which enables thermogenesis.

In small and hibernating mammals, the size and activity of BAT depend on the respective adaption to a cold stimulus. Thus, in response to chronic cold, the amount 


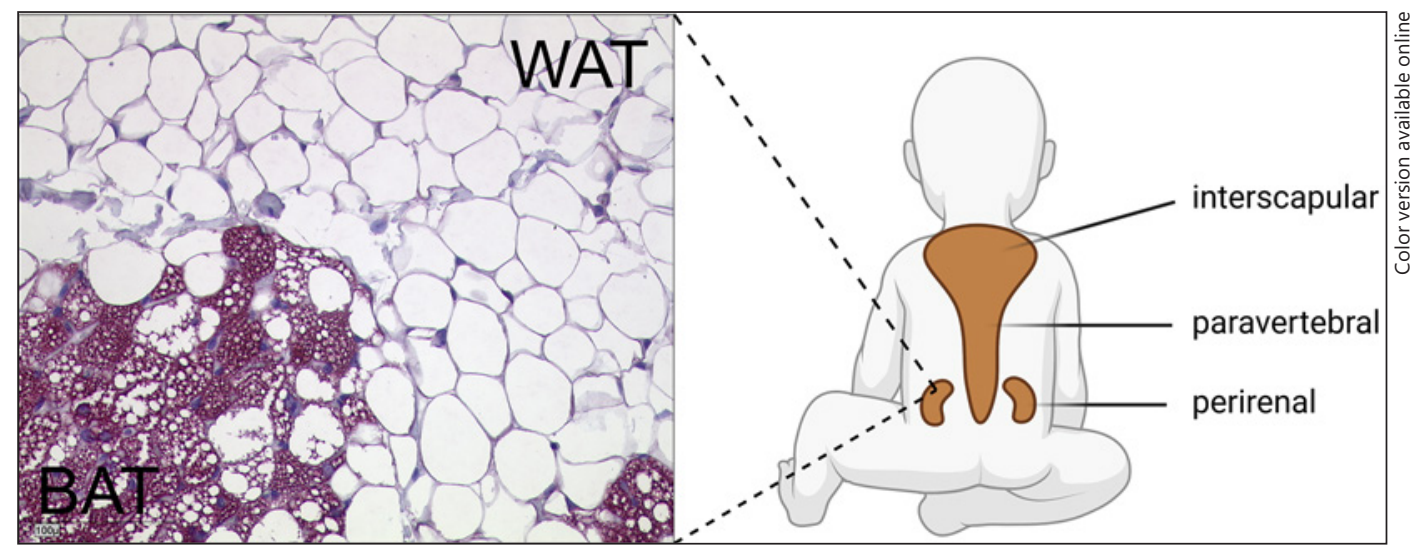

Fig. 1. Histological appearance and localization of BAT in children. Perirenal adipose tissue stained for UCP1, transition between BAT and WAT. Schematic illustration of BAT localization in children (created with Biorender.com). BAT, brown adipose tissue; WAT, white adipose tissue; UCP1, uncoupling protein 1.

of BAT in rodents visibly increases macroscopically [1]. In addition, the so-called "beige" adipocytes are recruited in WAT in a process referred to as WAT "browning" [2].

In humans, BAT was described for the first time in fetuses as a structure in the neck which was reminiscent to BAT in rodents ("hibernating gland") [3]. Later, this finding was verified in a retrospective necropsy study investigating a cohort of infants aged $0-4$ weeks $[4,5]$. Of note, BAT was detected in all investigated neonates $[4,5]$. In contrast, the existence and functionality of BAT in adults has not been demonstrated until the beginning of this millennium.

\section{BAT Activity in Humans beyond the Neonatal Period}

Although anatomical studies in the 1970s already indicated the presence of BAT in adults $[6,7]$, it was thought that BAT does not significantly contribute to thermogenesis in adults as other modes of thermogenesis (e.g., shivering) are available. This view changed between 2007 and 2009, when different laboratories were able to provide decisive evidence of functionally active BAT in adults. Using ${ }^{18} \mathrm{~F}$-fluorodesoxyglucose-PET/CT (18FDG-PET) images, the activity of BAT has been specifically investigated for the first time in living human adults. This method, originally used in tumor diagnosis, visualizes glucose uptake in metabolically highly active organs such as tumors, CNS, but also BAT. In tissue samples taken from 18FDGPET-positive areas, presence of UCP1-positive adipocytes could be verified, thus clearly proving presence of functional BAT [8].

BAT in Children and Its Metabolic Function
In retrospective $\mathrm{PET} / \mathrm{CT}$ evaluations of approximately 2,000 patients, BAT activity was found in $7.5 \%$ of women and $3.1 \%$ of men studied. The average amount of BAT mass was estimated to be $12.3 \mathrm{~g}$ in women and $11.6 \mathrm{~g}$ in men [9]. To visualize the cold inducibility of BAT, subjects were studied both at room temperature and after cold exposure. On average, cold increases 18FDG uptake in the neck region about 15 -fold [8]. Of note, BAT activity was significantly decreased in overweight subjects compared to lean controls [10]. In particular, BAT activity correlated inversely with BMI as well as relative body fat and positively with basal metabolic rate [10], suggesting that BAT may play a role in body weight regulation. BAT activity was also higher in younger individuals [11] and more likely to be detected in the winter term [12].

In more recent studies in which subjects were exposed to colder ambient temperatures in a controlled manner, the frequency rates of detection of functionally active BAT were much higher, ranging from 20 to $31 \%$ in obese patients $[13,14]$ and 40 to $100 \%$ in lean subjects $[8,9$, 15-19]. Despite this high variability, these findings are impressive and go against the previous doctrine that only neonates possess functionally active BAT.

\section{Development and Anatomy of BAT in Children and Adolescents}

BAT is localized in different anatomical regions in humans. However, differences in the anatomical localization of BAT and its amount are found between neonates and adults, suggesting dynamics in the development of 


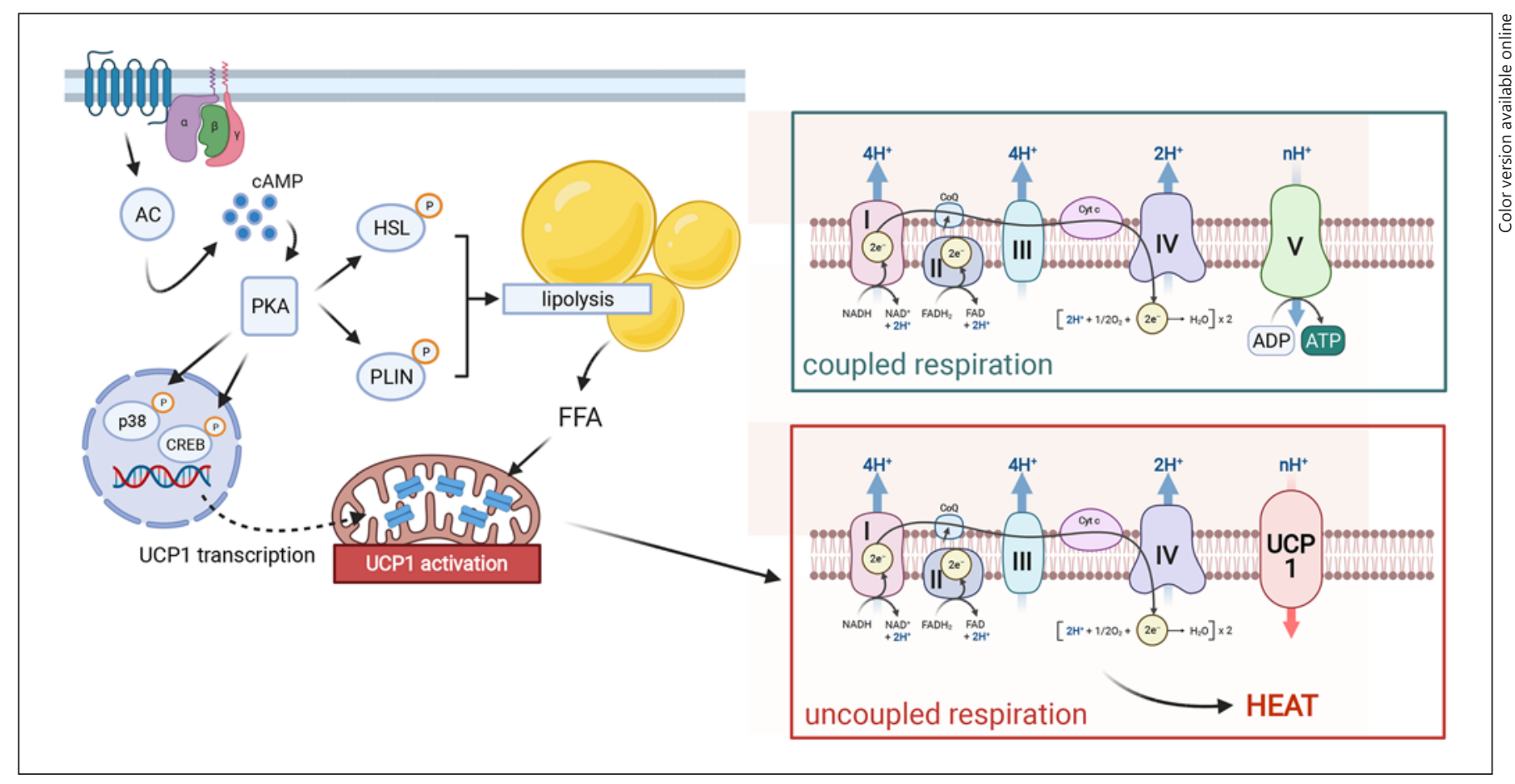

Fig. 2. UCP1-mediated thermogenesis. UCP1 activity is triggered by lipolysis upon beta-adrenergic stimulation. Upon chronic treatment, UCP1 expression is elevated via p38- and CREB-dependent gene transcription. Illustration created with Biorender.com. UCP1, uncoupling protein 1.

BAT. Histological examinations found evidence of BAT in humans already in the sixth month of pregnancy [20, 21]. Correspondingly, ultrastructural analyses could find evidence for BAT in prematurely born (25-27 weeks) infants [22]. Most data regarding the prevalence of BAT in neonates, children, and adolescents have been collected from retrospective PET/CT examinations; however, more recent data were assessed from MRI. On average, detectable BAT activity is found in 53\% (aged 4-19.9 years) [23] and 43-59\% (aged 5-21 years) [24] of subjects. In anatomical studies, BAT has been found in fetuses and neonates between the scapulae (interscapular), along the cervical muscles to below the clavicles (supraclavicular and axillary), along the trachea, esophagus, and greater mediastinal vessels, and surrounding the intercostal arteries. In the abdomen, the largest BAT depots are found in the perirenal region $[4,25]$. In a more recent study, tissue samples were obtained from 13 children and adolescents. Except for the interscapular depot, the aforementioned localizations were also detected here [25]. In adults, BAT was found mainly in supraclavicular and cervical and less frequently in costovertebral, upper mediastinum, and axillary regions [2]. A comparative histologic study from the 1970s also showed that certain areas of BAT are preserved in adults (cervical, costovertebral, mediastinal, and renal), whereas other depots reduced (e.g., interscapular) [6].

BAT prevalence increases significantly after birth with a maximum at late pubertal age $[7,23]$, suggesting that BAT plays a role in adolescent development. Indeed, associations between BAT activity and muscle or bone mass in children have been described [26, 27]. In one study, $\mathrm{PET} / \mathrm{CT}$ was used to investigate BAT activity in children with cancer. In $n=30$ of 71 (42\%) children investigated, BAT activity was found. Compared to patients without BAT activity, muscle mass in the neck area as well as in the buttocks was significantly increased (by 33-55\%), independently of age, BMI, and subcutaneous fat mass [26]. In another study with 40 children and adolescents, a positive correlation of BAT activity with bone density and mass was shown. This was independent of body size, body weight, and gender and of the patients studied [27]. Even though it has been frequently reported that BAT prevalence is higher in women compared to men $[28,29]$, sex differences in BAT presence or volume in children and adolescence appears to be controversial $[23,27,30]$. 
Nonetheless, growing evidence from rodent models and clinical studies leads to the conclusion that sex hormones have an important impact on BAT development and activity with estrogens inducing a stimulatory effect on BAT activity and androgens an inhibitory one (reviewed in [31]).

\section{Thermogenic Induction on the Cellular Level}

The functionally central molecule in BAT is UCP1, being responsible for nonshivering thermogenesis. It belongs to a family of mitochondrial transport proteins, of which only UCP1 plays a role in adaptive thermogenesis. UCP1 is found in the inner mitochondrial membrane of brown adipocytes and occupies approximately $5 \%$ of the total mitochondrial mass in cold-acclimated rodents [32]. In mice, targeted silencing of UCP1 expression results in strongly induced cold sensitivity, that is, $85 \%$ of animals are unable to maintain constant body temperature during cold exposure [33]. Upon its activation, UCP1 uncouples the proton gradient established by the respiratory chain from ATP synthesis by transporting protons across the inner mitochondrial membrane with the gradient into the mitochondrial matrix. The energy from the cellular oxidation reactions is released as heat. In BAT, UCP1 is inhibited by purine nucleotides (GDP, GTP, ADP, and ATP) and is activated by fatty acids [34]. Therefore, the activity of BAT is coupled to lipolysis [34]. During cold exposure, norepinephrine is released from the nerve terminals of the sympathetic nervous system, which can bind to $B 3$-adrenergic receptors on the surface of brown adipocytes. This leads to activation of adenylate cyclase and an increase in intracellular cAMP levels. Elevated cAMP levels then activate protein kinase $\mathrm{A}$, which in turn both activates hormone-sensitive lipase and phosphorylates perilipin, which then dissociates from lipid vesicles and renders them vulnerable to hormone-sensitive lipase. The released fatty acids cause a conformational change in the UCP1 molecule, thereby activating it [35] (Fig. 2).

Besides being activators of UCP1, fatty acids provide a major energy source for the increased energy demand in BAT during thermogenesis (as reviewed in [36]). In case of defective lipolysis within the brown adipocytes or depleted intracellular lipid stores, dietary or WAT-derived fatty acids can also be used for thermogenesis [37]. Mouse studies have further demonstrated that if fatty acids are not available as an energy source, glucose can be used as a substitute [37]. Although the contribution of glucose as

BAT in Children and Its Metabolic Function an energy source in thermogenesis has been considered minor (2-16\%) [36], it is nevertheless essential [38]. The different routes of glucose in brown adipocytes have been comprehensively reviewed [36]. Glucose is taken up by glucose transporters GLUT1 and GLUT4, and the majority is further converted to pyruvate via glycolysis. Interestingly, due to recent mouse studies, pyruvate is not directly oxidized within the mitochondria to provide energy for thermogenesis, but instead used to drive de novo lipogenesis to generate triglycerides. These are then subsequently liberated by lipolysis to activate UCP1 and to provide energy by beta oxidation [36]. The reason for this indirect route of glucose has not been resolved but may help us to understand the role of BAT in systemic glucose metabolism.

\section{Impact of BAT on Systemic Energy Metabolism and the Metabolic Syndrome}

Recent estimates from PET/CT studies suggest that the average mass of BAT in humans is approximately $50-80$ $\mathrm{g}[8,39]$. Current studies address the question of whether BAT has relevance in humans with respect to energy balance, metabolism, and ultimately with respect to body weight regulation (Table 1). Indeed, the first human studies already showed a positive correlation of BAT activity with resting metabolic rate after moderate cold exposure of the subjects $[9,19]$. Three other studies address the long-term recruitment of BAT by mild chronic cold exposure [40-42]. In the first study, subjects $(n=17)$ were exposed to a temperature of $15-16^{\circ} \mathrm{C}$ for 2 to $6 \mathrm{~h}$ daily over a 10-day period. This resulted in an increase in BAT activity as well as nonshivering thermogenesis [41]. In the second study, daily cold exposure for $2 \mathrm{~h}$ over a period of 4 weeks resulted in increased glucose uptake in the BAT as well as increased BAT activity in PET/CT, but an increase in BAT volume by an average of $45 \%$ was also measured [40]. In the third study, individuals with absent or low cold-stimulated BAT activity were selected from a group of subjects $(n=51)$ and subjected to 6 weeks of cold acclimation. This resulted not only in increased BAT activity but also in a reduction in fat mass compared to a control group. Moreover, the increase in BAT activity was negatively associated with body fat mass [42].

A large number of studies found a correlation between the prevalence and activity of BAT with BMI, percent fat mass, and respective plasma glucose levels $[8,9,13,19$, $29,30,43-45]$. In children, a retrospective study also found a negative association of BAT activity with BMI 
Table 1. Summary of published findings on BAT in children and adolescents

\begin{tabular}{|c|c|c|c|c|c|c|}
\hline Reference & $\begin{array}{l}\text { BAT detection } \\
\text { method }\end{array}$ & Cohort size & $\begin{array}{l}\text { Age, } \\
\text { years }\end{array}$ & $\begin{array}{l}\text { BAT } \\
\text { prevalence, } \%\end{array}$ & $\begin{array}{l}\text { BAT volume, } \\
\mathrm{cm}^{3}\end{array}$ & $\begin{array}{l}\text { Association of BAT with metabolic or } \\
\text { developmental parameters }\end{array}$ \\
\hline Gilsanz et al. [23] & PET & 73 & $4-19.9$ & 59 & $<100-1,200$ & \\
\hline Drubach et al. [24] & Retrospective PET & $5-21$ & 172 & 44.2 & $\mathrm{n} / \mathrm{a}$ & \\
\hline Gilsanz et al. [26] & PET & 30 & $6-20$ & 42 & $\mathrm{n} / \mathrm{a}$ & $\begin{array}{l}\text { Higher muscle volume in children with } \\
\text { detectable BAT }\end{array}$ \\
\hline Malpique et al. [30] & $\begin{array}{l}\text { Thermography, } \\
\text { cold-induced }\end{array}$ & 86 & $6.5-10.2$ & $\mathrm{n} / \mathrm{a}$ & $\mathrm{n} / \mathrm{a}$ & $\begin{array}{l}\text { Intensity of thermogenic response negatively } \\
\text { associated with visceral fat content, liver fat, } \\
\text { fasting glucose, and insulin levels }\end{array}$ \\
\hline Lundström et al. [44] & MRI & 143 & $10-20$ & $\mathrm{n} / \mathrm{a}$ & $\mathrm{n} / \mathrm{a}$ & $\begin{array}{l}\text { Associations of BAT measures with BMI and } \\
\text { glucose parameters }\end{array}$ \\
\hline Chalfant et al. [46] & PET & 32 & $6.8-18.5$ & 59 & $\mathrm{n} / \mathrm{a}$ & $\begin{array}{l}\text { BAT presence negatively associated with WAT } \\
\text { volume }\end{array}$ \\
\hline Symonds et al. [47] & $\begin{array}{l}\text { Thermography, } \\
\text { cold-induced }\end{array}$ & $\begin{array}{r}7 \text { ( }(3-8 \text { yrs }) \\
12 \text { (13-18 yrs) } \\
7 \text { ( } 35-58 \text { yrs })\end{array}$ & $\begin{array}{c}3-8 \\
13-18 \\
35-58\end{array}$ & $\mathrm{n} / \mathrm{a}$ & $\mathrm{n} / \mathrm{a}$ & $\begin{array}{l}\text { Age-related decline in BAT activation upon } \\
\text { cooling }\end{array}$ \\
\hline Rockstroh et al. [65] & Histology & 87 & $0.1-18.2$ & 10.3 & $\mathrm{n} / \mathrm{a}$ & \\
\hline
\end{tabular}

BAT, brown adipose tissue; WAT, white adipose tissue.

[24]. The association between body weight development and BAT activity was further investigated in a study of children with tumor disease. Accordingly, children with positive BAT status after therapy gained significantly less body weight and WAT mass than children without significant BAT activity [46]. A recent study examining BAT mass in children and adolescents by MRI demonstrated as well that BAT volume was negatively associated with measures of obesity [44]. There is therefore ample evidence that BAT and BAT activity have an impact on stored energy in adipose tissue.

Acute cold exposure increases body temperature above the supraclavicular region in some human studies and stimulates glucose and fatty acid uptake as well as blood flow and oxidative metabolism in the BAT $[16,39,47]$. This indicates activation of the BAT by cold stimulation and increased glucose and fatty acid metabolism. In a comparative study with BAT-negative and BAT-positive subjects, a positive influence of the BAT on insulin sensitivity after cold exposure was also demonstrated [8]. The subjects were exposed to cold for a period of $8 \mathrm{~h}$ on an individualized basis. In the BAT-positive group, cold ex- posure increased resting metabolic rate in the study subjects, which remained unchanged in BAT-negative subjects. This increase could be explained to 30 and $70 \%$ by an increase in glucose and lipid oxidation, respectively. In addition, cold exposure improved insulin sensitivity in the BAT-positive group [48]. These results suggest that increased BAT activity under cold exposure leads to an improvement in metabolism.

Besides cold exposure, BAT can also be pharmacologically activated. Treatment of $n=12$ subjects with mirabegron, a 33 -receptor agonist, resulted in a significant increase in BAT activity on PET/CT. This increase was also associated with an increase in resting metabolic rate [43]. Chronic mirabegron treatment over a period of 4 weeks increased BAT metabolic activity and improved lipid and glucose metabolism in a clinical trial including healthy women [49]. Improvement of glucose homeostasis upon mirabegron treatment has been shown in obese men as well [50]. Interestingly, treatment also resulted in an increase of BAT markers in subcutaneous adipose tissue, indicating that browning occurred upon treatment [50]. 
Several studies investigated the activity of BAT in children with metabolic disorders without cold exposure [30, $44,45]$. Here, parameters of glucose metabolism (2-h glucose during OGTT and HOMA-IR) were negatively associated with BAT mass, suggesting a relationship between BAT and glucose metabolism and insulin sensitivity in children [44]. This is supported by another study showing that BAT activity (as measured by supraclavicular infrared thermography) was negatively associated with HOMA-IR, liver volume, and liver fat content in a cohort of $n=84$ prepubertal children [30]. In children with type 1 diabetes mellitus, cold-induced supraclavicular temperature was lower compared to nondiabetic children [45], suggesting that BAT activity is partially mediated by insulin. Indeed, it has been shown earlier in adults using PET/CT that BAT can be activated by cold as well as by insulin, and that this effect was markedly reduced in obesity [13]. The connection between insulin sensitivity and BAT activity thus seems to be evident. BAT is thus another important influencing factor in the context of the metabolic syndrome.

\section{BAT Activity and Thyroid Hormone Status}

Another determinant of BAT activity is the thyroid axis [51]. In adults, glucose uptake into BAT was approximately 3 times higher in patients with hyperthyroidism as compared to controls [52]. These changes were reversible after therapeutically reaching euthyroidism, demonstrating that BAT activity is directly dependent on thyroid status [52]. This has recently been shown in children as well, where response to cold, as measured by thermography in the supraclavicular region, is delayed in girls with autoimmune hypothyroidism [53] compared to healthy controls.

\section{Determination of Brown Adipocytes and Plasticity of Adipose Tissue}

As shown above, chronic cold exposure even leads to an increase in BAT mass. This recruitment of BAT could be explained either by a conversion of white adipocytes into brown adipocytes or by a differentiation of brown adipocytes from progenitor cells. In addition to white and brown adipocytes, a third cell type of adipocytes exists that has characteristics of brown adipocytes but is found in WAT. These so-called "beige" adipocytes express the BAT marker UCP1 and are capable of thermogenesis. In mouse

BAT in Children and Its Metabolic Function models, it has been shown that beige adipocytes can either differentiate from specific progenitor cells $[54,55]$ or transdifferentiate from white adipocytes [56-58]. In recent years, more and more factors have been identified to play a role in the differentiation of these beige adipocytes, such as incretins [59], natriuretic peptides [60], bone morphogenetic proteins $[61,62]$, and FGF21 $[63,64]$. Of note, BAT markers can be detected in WAT in both children [65] and adults [66]. Based on expression studies of specific adipose tissue markers in mice, recent studies have attempted to further characterize the composition of human BAT and elucidate whether adult BAT is remnant classical BAT or neoplasms in the form of beige fat. Thus, interscapular adipose tissue in neonates shows an expression pattern similar to that of classical murine BAT [12]. Similarly, adipose tissue-expressing markers of beige adipocytes are found in the supraclavicular region of children and adults $[12,25,55]$. In contrast, however, there are also studies demonstrating an expression pattern in human BAT similar to classical BAT [67-69]. This is probably explained by a strong heterogeneity of adipose tissue in humans. It has been demonstrated that the proportion of classical brown adipocytes in the neck increases with the depth of adipose tissue localization [67]. Indeed, UCP1positive adipocytes in humans are often found as islands in WAT or at least in the vicinity of white adipocytes, which makes a mixing of both cell types likely in the genetic characterization of adipose tissue.

We [69] and others [2, 11, 67, 68, 70] have demonstrated that stromal vascular cells isolated from adult adipose tissue differentiate into either white or brown adipocytes depending on their localization. In this way, it was shown that in vitro differentiated adipocytes from BAT also exhibit ex vivo functional characteristics of brown adipocytes, for example, increased uncoupled respiration compared to white adipocytes $[67,69]$. This indicates that different progenitor cells of white and brown/ beige adipocytes also exist in humans, which can be distinguished by different gene expression patterns $[69,70]$.

\section{Conclusions}

Studies in recent years have not only demonstrated that functionally active BAT exists in humans at all ages but have also shown that it can have an impact on energy balance, body weight development, insulin sensitivity, and glucose and lipid metabolism. Recent data clearly demonstrate that BAT prevalence increases during puberty. Positive associations of BAT with skeletal muscle and bone 
mass suggest an influence of BAT in juvenile development. Furthermore, studies in children indicate that BAT activity plays a beneficial role in insulin sensitivity as well as in glucose and lipid metabolism. Although more sophisticated clinical and basic studies are necessary to better understand the relationship between BAT and metabolism in humans, the findings to date are promising and make BAT in humans a valuable field of research.

\section{Conflict of Interest Statement}

The authors have no conflicts of interest to declare.

\section{Funding Sources}

D.T. is supported by the German Research Foundation (TE912/2-2).

\section{Author Contributions}

D.T. and M.W. were involved in conceptualization; D.T. was involved in writing - original draft preparation; D.T. and M.W. were involved in writing - review and editing; D.T. was involved in visualization; both authors have read and agreed to the published version of the manuscript.

\section{References}

1 Cinti S. The adipose organ: morphological perspectives of adipose tissues. Proc Nutr Soc. 2001;60(3):319-28.

2 Zingaretti MC, Crosta F, Vitali A, Guerrieri $\mathrm{M}$, Frontini A, Cannon B, et al. The presence of UCP1 demonstrates that metabolically active adipose tissue in the neck of adult humans truly represents brown adipose tissue. FASEB J. 2009;23(9):3113-20.

3 Hatai S. On the presence in human embryos of an interscapular gland corresponding to the so-called hibernating gland of lower mammals. Anat Anz. 1902;21:369-73.

4 Aherne W, Hull D. The site of heat production in the newborn infant. Proc R Soc Med. 1964 Dec;57(12):1172-3.

5 Aherne W, Hull D. Brown adipose tissue and heat production in the newborn infant. J Pathol Bacteriol. 1966;91(1):223-34.

6 Heaton JM. The distribution of brown adipose tissue in the human. J Anat. 1972;112(Pt 1):35-9.

7 Lean ME, James WP, Jennings G, Trayhurn P. Brown adipose tissue uncoupling protein content in human infants, children and adults. Clin Sci. 1986 Sep;71(3):291-7.

8 Virtanen KA, Lidell ME, Orava J, Heglind M, Westergren R, Niemi T, et al. Functional brown adipose tissue in healthy adults. $\mathrm{N}$ Engl J Med. 2009;360(15):1518-25.

9 Van Marken Lichtenbelt WD, Vanhommerig JW, Smulders NM, Drossaerts JM, Kemerink GJ, Bouvy ND, et al. Cold-activated brown adipose tissue in healthy men. $\mathrm{N}$ Engl J Med. 2009;360(15):1500-8.

10 Cypess AM, Lehman S, Williams G, Tal I, Rodman D, Goldfine AB, et al. Identification and importance of brown adipose tissue in adult humans. N Engl J Med. 2009;360(15): 1509-17.

11 Lee P, Swarbrick MM, Zhao JT, Ho KK. Inducible brown adipogenesis of supraclavicular fat in adult humans. Endocrinology. 2011; 152(10):3597-602.

12 Lidell ME, Betz MJ, Dahlqvist Leinhard O, Heglind M, Elander L, Slawik M, et al. Evi- dence for two types of brown adipose tissue in humans. Nat Med. 2013;19(5):631-4.

13 Orava J, Nuutila P, Noponen T, Parkkola R, Viljanen T, Enerbäck S, et al. Blunted metabolic responses to cold and insulin stimulation in brown adipose tissue of obese humans. Obesity. 2013;21:2279-87.

14 Vijgen GH, Bouvy ND, Teule GJ, Brans B, Hoeks J, Schrauwen P, et al. Increase in brown adipose tissue activity after weight loss in morbidly obese subjects. J Clin Endocrinol Metab. 2012;97(7):E1229-33.

15 Cypess AM, Chen YC, Sze C, Wang K, English J, Chan O, et al. Cold but not sympathomimetics activates human brown adipose tissue in vivo. Proc Natl Acad Sci U S A. 2012; 109(25):10001-5.

16 Muzik O, Mangner TJ, Granneman JG. Assessment of oxidative metabolism in brown fat using PET imaging. Front Endocrinol. 2012;3:15.

17 Saito M, Okamatsu-Ogura Y, Matsushita M, Watanabe K, Yoneshiro T, Nio-Kobayashi J, et al. High incidence of metabolically active brown adipose tissue in healthy adult humans: effects of cold exposure and adiposity. Diabetes. 2009;58(7):1526-31.

18 Yoneshiro T, Aita S, Kawai Y, Iwanaga T, Saito M. Nonpungent capsaicin analogs (capsinoids) increase energy expenditure through the activation of brown adipose tissue in humans. Am J Clin Nutr. 2012;95(4):845-50.

19 Yoneshiro T, Aita S, Matsushita M, Kameya T, Nakada K, Kawai Y, et al. Brown adipose tissue, whole-body energy expenditure, and thermogenesis in healthy adult men. Obesity (Silver Spring). 2011 Jan;19(1):13-6.

20 Merklin RJ. Growth and distribution of human fetal brown fat. Anat Rec. 1974;178(3): $637-45$.

21 Moragas A, Torán N. Prenatal development of brown adipose tissue in man. A morphometric and biomathematical study. Biol Neonate. 1983;43(1-2):80-5.

22 Zancanaro C, Carnielli VP, Moretti C, Benati D, Gamba P. An ultrastructural study of brown adipose tissue in pre-term human new-borns. Tissue Cell. 1995;27(3):339-48.

23 Gilsanz V, Smith ML, Goodarzian F, Kim M, Wren TA, Hu HH. Changes in brown adipose tissue in boys and girls during childhood and puberty. J Pediatr. 2012 Apr;160(4):6049.e1.

24 Drubach LA, Palmer EL 3rd, Connolly LP, Baker A, Zurakowski D, Cypess AM. Pediatric brown adipose tissue: detection, epidemiology, and differences from adults. J Pediatr. 2011 Aug;159(6):939-44.

25 Sharp LZ, Shinoda K, Ohno H, Scheel DW, Tomoda E, Ruiz L, et al. Human BAT possesses molecular signatures that resemble beige/ brite cells. PLoS One. 2012;7(11):e49452.

26 Gilsanz V, Chung SA, Jackson H, Dorey FJ, $\mathrm{Hu} \mathrm{HH}$. Functional brown adipose tissue is related to muscle volume in children and adolescents. J Pediatr. 2011;158(5):722-6.

27 Ponrartana S, Aggabao PC, $\mathrm{Hu} \mathrm{HH}, \mathrm{Al}-$ drovandi GM, Wren TA, Gilsanz V. Brown adipose tissue and its relationship to bone structure in pediatric patients. J Clin Endocrinol Metab. 2012;97(8):2693-8.

28 Cypess AM, Lehman S, Williams G, Tal I, Rodman D, Goldfine AB, et al. Identification and importance of brown adipose tissue in adult humans. N Engl J Med. 2009;360(15): 1509-17.

29 Pfannenberg C, Werner MK, Ripkens S, Stef I, Deckert A, Schmadl M, et al. Impact of age on the relationships of brown adipose tissue with sex and adiposity in humans. Diabetes. 2010;59(7):1789-93.

30 Malpique R, Gallego-Escuredo JM, Sebastiani G, Villarroya J, López-Bermejo A, de Zegher $\mathrm{F}$, et al. Brown adipose tissue in prepubertal children: associations with sex, birthweight, and metabolic profile. Int J Obes. 2019;43(2): 384-91.

31 Kaikaew K, Grefhorst A, Visser JA. Sex differences in brown adipose tissue function: sex hormones, glucocorticoids, and their crosstalk. Front Endocrinol. 2021 April;12:1-15. 
32 Stuart JA, Harper JA, Brindle KM, Jekabsons $\mathrm{MB}$, Brand MD. A mitochondrial uncoupling artifact can be caused by expression of uncoupling protein 1 in yeast. Biochem J. 2001 Jun 15;356(Pt 3):779-89.

33 Enerbäck S, Jacobsson A, Simpson EM, Guerra $\mathrm{C}$, Yamashita $\mathrm{H}$, Harper ME, et al. Mice lacking mitochondrial uncoupling protein are cold-sensitive but not obese. Nature. 1997; 387(6628):90-4.

34 Cannon B, Nedergaard J. Brown adipose tissue: function and physiological significance. Physiol Rev. 2004;84(1):277-359.

35 Divakaruni AS, Humphrey DM, Brand MD. Fatty acids change the conformation of uncoupling protein 1 (UCP1). J Biol Chem. 2012;287(44):36845-53.

36 Hankir MK, Klingenspor M. Brown adipocyte glucose metabolism: a heated subject. EMBO Rep. 2018;19(9):e46404.

37 Shin H, Ma Y, Chanturiya T, Cao Q, Wang Y, Kadegowda AKG, et al. Lipolysis in brown adipocytes is not essential for cold-induced thermogenesis in mice. Cell Metab. 2017;26: 764-77.e5.

38 Skjoldborg N, Isidor MS, Cheung A, Winther S, Hansen JB, Quistorff B, et al. Restricting glycolysis impairs brown adipocyte glucose and oxygen consumption. Am J Physiol Metab. 2017;314(3):E214-23.

39 Ouellet V, Labbé SM, Blondin DP, Phoenix S, Guérin B, Haman F, et al. Brown adipose tissue oxidative metabolism contributes to energy expenditure during acute cold exposure in humans. J Clin Invest. 2012;122(2):545-52.

40 Blondin DP, Labbé SM, Tingelstad HC, Noll C, Kunach M, Phoenix S, et al. Increased brown adipose tissue oxidative capacity in cold-acclimated humans. J Clin Endocrinol Metab. 2014;99(3):E438-46.

41 Van Der Lans AA, Hoeks J, Brans B, Vijgen GH, Visser MG, Vosselman MJ, et al. Cold acclimation recruits human brown fat and increases nonshivering thermogenesis. J Clin Invest. 2013;123(8):3395-403.

42 Yoneshiro T, Aita S, Matsushita M, Kayahara T, Kameya T, Kawai Y, et al. Recruited brown adipose tissue as an antiobesity agent in humans. J Clin Invest. 2013;123(8):3404-8.

43 Cypess AM, Weiner LS, Roberts-Toler C, Franquet Elía E, Kessler SH, Kahn PA, et al. Activation of human brown adipose tissue by a $\beta 3$-adrenergic receptor agonist. Cell Metab. 2015;21(1):33-8.

44 Lundström E, Ljungberg J, Andersson J, Manell H, Strand R, Forslund A, et al. Brown adipose tissue estimated with the magnetic resonance imaging fat fraction is associated with glucose metabolism in adolescents. Pediatr Obes. 2019;14(9):e12531.

45 Law JM, Morris DE, Robinson L, Randell T, Denvir L, Symonds ME, et al. Reduced brown adipose tissue-associated skin temperature following cold stimulation in children and adolescents with type 1 diabetes. Pediatr Diabetes. 2021 May;22(3):407-416.
46 Chalfant JS, Smith ML, Hu HH, Dorey FJ, Goodarzian $\mathrm{F}, \mathrm{Fu} \mathrm{CH}$, et al. Inverse association between brown adipose tissue activation and white adipose tissue accumulation in successfully treated pediatric malignancy. Am J Clin Nutr. 2012 May;95(5):1144-9.

47 Symonds ME, Henderson K, Elvidge L, Bosman C, Sharkey D, Perkins AC, et al. Thermal imaging to assess age-related changes of skin temperature within the supraclavicular region co-locating with brown adipose tissue in healthy children. J Pediatr. 2012;161(5):8928 .

48 Chondronikola M, Volpi E, Børsheim E, Porter C, Annamalai P, Enerbäck S, et al. Brown adipose tissue improves whole-body glucose homeostasis and insulin sensitivity in humans. Diabetes. 2014 Dec;63(12):4089-99.

49 O'Mara AE, Johnson JW, Linderman JD, Brychta RJ, McGehee S, Fletcher LA, et al. Chronic mirabegron treatment increases human brown fat, HDL cholesterol, and insulin sensitivity. J Clin Invest. 2020 May;130(5): 2209-19.

50 Finlin BS, Memetimin H, Zhu B, Confides AL, Vekaria HJ, El Khouli RH, et al. The $\beta 3$ adrenergic receptor agonist mirabegron improves glucose homeostasis in obese humans. J Clin Invest. 2020 May;130(5):2319-31.

51 Bianco AC, McAninch EA. The role of thyroid hormone and brown adipose tissue in energy homoeostasis. Lancet Diabetes Endocrinol. 2013 Nov; 1(3):250-8.

52 Lahesmaa M, Orava J, Schalin-Jäntti C, Soinio M, Hannukainen JC, Noponen T, et al. Hyperthyroidism increases brown fat metabolism in humans. J Clin Endocrinol Metab. 2014 Jan;99(1):E28-35.

53 Law JM, Morris DE, Astle V, Finn E, Muros JJ, Robinson LJ, et al. Brown adipose tissue response to cold stimulation is reduced in girls with autoimmune hypothyroidism. J Endocr Soc. 2019 Oct;3(12):2411-26

54 Wang QA, Tao C, Gupta RK, Scherer PE. Tracking adipogenesis during white adipose tissue development, expansion and regeneration. Nat Med. 2013;19(10):1338-44.

$55 \mathrm{Wu}$ J, Boström P, Sparks LM, Ye L, Choi JH, Giang $\mathrm{AH}$, et al. Beige adipocytes are a distinct type of thermogenic fat cell in mouse and human. Cell. 2012;150(2):366-76.

56 Barbatelli G, Murano I, Madsen L, Hao Q, Jimenez M, Kristiansen $\mathrm{K}$, et al. The emergence of cold-induced brown adipocytes in mouse white fat depots is determined predominantly by white to brown adipocyte transdifferentiation. Am J Physiol Endocrinol Metab. 2010;298(6):E1244-53.

57 Himms-Hagen J, Melnyk A, Zingaretti MC, Ceresi E, Barbatelli G, Cinti S. Multilocular fat cells in WAT of CL-316243-treated rats derive directly from white adipocytes. Am J Physiol Cell Physiol. 2000;279(3):C670-81.

58 Rosenwald M, Perdikari A, Rülicke T, Wolfrum C. Bi-directional interconversion of brite and white adipocytes. Nat Cell Biol. 2013;15(6):659-67.
59 Shimasaki T, Masaki T, Mitsutomi K, Ueno $\mathrm{D}$, Gotoh K, Chiba S, et al. The dipeptidyl peptidase-4 inhibitor des-fluoro-sitagliptin regulates brown adipose tissue uncoupling protein levels in mice with diet-induced obesity. PLoS One. 2013;8(5):e63626.

60 Bordicchia M, Liu D, Amri EZ, Ailhaud G Dessì-Fulgheri $\mathrm{P}$, Zhang C, et al. Cardiac natriuretic peptides act via $\mathrm{p} 38 \mathrm{MAPK}$ to induce the brown fat thermogenic program in mouse and human adipocytes. J Clin Invest. 2012; 122(3):1022-36.

61 Tseng YH, Kokkotou E, Schulz TJ, Huang TL, Winnay JN, Taniguchi CM, et al. New role of bone morphogenetic protein 7 in brown adipogenesis and energy expenditure. Nature. 2008;454(7207):1000-4.

62 Xue R, Wan Y, Zhang S, Zhang Q, Ye H, Li Y Role of bone morphogenetic protein 4 in the differentiation of brown fat-like adipocytes. Am J Physiol Endocrinol Metab. 2014;306(4): E363-72.

63 Lee P, Linderman JD, Smith S, Brychta RJ, Wang J, Idelson C, et al. Irisin and FGF21 are cold-induced endocrine activators of brown fat function in humans. Cell Metab. 2014; 19(2):302-9.

64 Schlein C, Talukdar S, Heine M, Fischer AW, Krott LM, Nilsson SK, et al. Fgf21 lowers plasma triglycerides by accelerating lipoprotein catabolism in white and brown adipose tissues. Cell Metab. 2016 Mar 8;23(3):441-53.

65 Rockstroh D, Landgraf K, Wagner IV, Gesing J, Tauscher R, Lakowa N, et al. Direct evidence of brown adipocytes in different fat depots in children. PLoS One. 2015;10(2): e0117841.

66 Kern PA, Finlin BS, Zhu B, Rasouli N, McGehee RE, Westgate PM, et al. The effects of temperature and seasons on subcutaneous white adipose tissue in humans: evidence for thermogenic gene induction. J Clin Endocrinol Metab. 2014;99(12):E2772.

67 Cypess AM, White AP, Vernochet C, Schulz T), Xue R, Sass CA, et al. Anatomical localization, gene expression profiling and functional characterization of adult human neck brown fat. Nat Med. 2013;19(5):635-9.

68 Jespersen NZ, Larsen TJ, Peijs L, Daugaard S, Homøe P, Loft A, et al. A classical brown adipose tissue mRNA signature partly overlaps with brite in the supraclavicular region of adult humans. Cell Metab. 2013;17(5):798805 .

69 Tews D, Schwar V, Scheithauer M, Weber T, Fromme T, Klingenspor M, et al. Comparative gene array analysis of progenitor cells from human paired deep neck and subcutaneous adipose tissue. Mol Cell Endocrinol. 2014 Sep;395(1-2):41-50.

70 Shinoda K, Luijten IH, Hasegawa Y, Hong H, Sonne SB, Kim M, et al. Genetic and functional characterization of clonally derived adult human brown adipocytes. Nat Med. 2015 Apr;21(4):389-94.
BAT in Children and Its Metabolic Function
Horm Res Paediatr 2022;95:104-111 DOI: $10.1159 / 000518353$ 